Д.С. Бірюков, В.М. Бурлаков

\title{
ВПЛИВ СУЧАСНИХ КІБЕР-ЗАГРОЗ НА ЕФЕКТИВНІСТЬ СИСТЕМ ФІЗИЧНОГО ЗАХИСТУ КРИТИЧНО ВАЖЛИВИХ ОБ'ЄКТІВ ТА ІНФРАСТРУКТУРИ
}

\begin{abstract}
Анотація: В роботі розглядається питання про необхідність врахування кіберзагроз при формуванні систем фізичного захисту критично важливих об'єктів та інфраструктури.

Ключові слова: вразливість автоматизованих систем управління, критична інфраструктура, системи фізичного захисту.
\end{abstract}

\section{Вступ}

Проблема забезпечення безпеки фрункціонування автоматизованих систем управління (АСУ) та АСУ технологічними процесами (АСУ ТП) на виробничих підприемствах критичної інфраструктури є багатоаспектною і включає нормативні, організаційні, технологічні, психологічні складові. В технологічному аспекті безпека АСУ пов'язана переважно з надійністю їх апаратного та програмного забезпечення, в організаційному - з дотриманням вимог фрізичного захисту. Психологічний аспект безпеки АСУ стосуеться здебільшого оцінки та прогнозування поведінки ліцензованого персоналу, а нормативний аспект представлений зводом регулюючих і інструктивних документів.

На кінець 80 -х років минулого сторіччя був накопичений значний досвід щодо проектного забезпечення та практичного оцінювання надійності АСУ та АСУ ТП, розроблені нормативні документи з питань надійності та ризик-менеджменту таких систем, включаючи державні і галузеві стандарти, опубліковано значну кількість наукових статей та десятки монографій [1-4].

Характерною особливістю останніх двадцяти років є значне зростання якості, в тому числі і надійності, елементної бази технічних засобів інформатизації поряд з суттевим підвищенням складності АСУ ТП. Розвиток інформаційних технологій (IT), апаратного забезпечення АСУ та комп'ютерних мереж створив умови для віддаленого управління технологічним процесом (ТП) на підприемствах, автоматизованого збору та аналізу необхідних даних, зміни параметрів (перепрограмування) контролерів ТП. Ці можливості розглядаються та активно використовуються керівництвом великих компаній, які $є$ операторами критично важливих об'ектів (КВО) промисловості та критичної інфрраструктури (КI), як способи оптимізації виробничих процесів, збору та підготовки аналітичних матеріалів для прийняття ділових рішень, зменшення витрат при роботі з підрядниками [5]. Компаніями виробниками елементної бази та АСУ можливість віддаленого керування АСУ ТП розглядається як

(c) Д.С. Бірюков, В.М. Бурлаков, 2012 
фактор зменшення витрат на цикл підтримки виробництва продукції. Проте, поряд із можливостями, що відкриваються, і економією коштів новітні технології привносять і значні загрози безпеці [6].

Загальносвітовою тенденцією е посилення тиску несанкціонованих втручань (кібер-атак) на корпоративні інформаційні системи. Так, за даними підрозділу Міністерства внутрішньої безпеки США (Команди готовності до комп'ютерних надзвичайних ситуацій - Computer Emergency Readiness Team) кількість кібер-атак на сервери та мережі, що обслуговують федеральні урядові структури, в 2010 році становила понад 41 тис. випадків, і в порівнянні з попереднім роком зросла майже на 40\% [7]. При нападах використовувалися вразливості програмного забезпечення, які не були виявлені і усунені в організаціях, що стали мішенню атаки.

Переломним моментом стало виявлення в 2010 році перших випадків зараження програмного забезпечення контролерів АСУ ТП на промислових підприемствах вірусом Stuxnet, що призвело до суттевих негативних наслідків на об'єктах атаки [8]. Тому виявлення цього вірусу на dроні його масштабних руйнівних здатностей значно піднесло актуальність завдань забезпечення безпеки, захисту від терористичних і криміногенних загроз, кібер-атак та інших видів зловмисного втручання (проникнення) і викликало необхідність вжити додаткових заходів щодо забезпечення безпеки промислових систем.

\section{2. Новітні кібер-загрози для АСУ ТП КВО та КI}

Відповідно до діючих нормативів промислові мережі, як правило, функціонують ізольовано не тільки від зовнішнього світу, а й від локальних мереж підприемства. Тому проникнення вірусу в системи моніторингу технологічних процесів визнавалося неможливим через, як вважалось, непереборне фрізичне розмежування мереж. Проте з різних причин, в основному через недотримання організаційно-технічних регламентів на об'єктах критичної інфраструктури, були допущені випадки проникнення шкідливого програмного коду Stuxnet в АСУ промислових об'ектів [8].

Ціллю реалізованих на даний час атак Stuxnet є системи автоматизованого управління SCADA WinCC/PCS7 виробництва компанії Siemens. Крім того хробак “бачить” в мережі і засоби локального управління (контролери) PLC Simatic виробництва компанії Siemens та здатен їх перепрограмовувати (тобто змінювати параметри режимів ТП), а також накопичувати і передавати данні отримані з них. Зважаючи на розповсюдженість таких контролерів можна оцінити масштаби небезпеки, оскільки вони складають основну частину АСУ ТП багатьох об'єктів критичної інфраструктури, стратегічного та військового призначення, як, наприклад, контролери устаткування AEC в Бушері (Іран), що вважаються експертами “ціллю” цієї кіберзброї.

Характерною особливістю вірусу Stuxnet $є$ його перенесення всередині підприємства (між комп'ютерами, які не з'єднані мережею) за допомо- 
гою зйомних носіїв інформації - заражених вірусом фрлеш накопичувачів (рис. 1).

локальна обчислювальна мережа

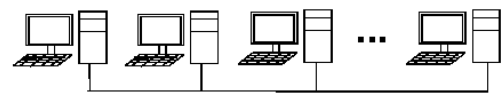

переносний пристрій заражений вірусом

APM моніторингу і контролю ТП (SCADA)

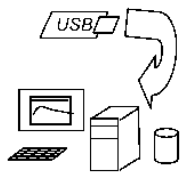

переносний пристрій заражений вірусом

комп'ютер, $з$ програмою Step 7 і досту-

пом до контролерів

контролери технологічних процесів

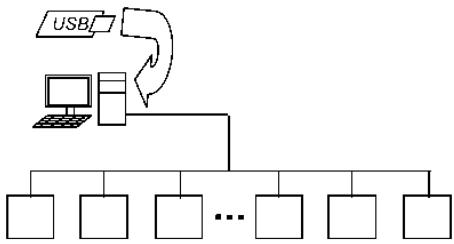

Рис. 1 - Атака Stuxnet

В жовтні 2011 р. фрахівці корпорації Symantec повідомили про появу нової кібер-загрози - Duqu, яка може стати передвісником наступної хвилі спрямованих атак на промислові підприемства [9]. На їх думку розробники нового вірусу, як найменш, мали доступ до вихідного коду “хробака" Stuxnet. На відміну від Stuxnet, що був створений для роботи у промислових АCУ ТП, Duqu є класичною шпигунською програмою для збору конфріденційної інформації. Ціль Duqu - дані про устаткування і автоматизовані системи, що використовуються для управління виробничим циклом, які потрібні для здійснення подальшого зловмисного нападу з використанням засобів на зразок Stuxnet.

В березні 2012 р. Команда готовності до комп'ютерних надзвичайних ситуацій Міністерства внутрішньої безпеки США оприлюднила інфрормацію про виявлені спроби втручання в роботу АСУ об'ектів газотранспортних систем [10]. Розслідування наслідків спроб втручання показало, що ці кібер-атаки належать до одніеї групи і пов'язані з фішинговою активністю, яка була спрямована проти персоналу компаній-операторів газотранспортних систем, починаючи з грудня 2011 р.

Аналізуючи наведені випадки здійснення кібер-атак, треба зазначити наступне. Характер і форми компютерних нападів, від яких має бути розроблений захист, можуть істотно розрізнятися. Але, незважаючи на різноманітність типів атак, наслідки від них на найвищому рівні, як правило, включають:

- несанкціонований доступ або перехоплення інформації (втрата конфіденційності); 
- несанкціонована зміна інформації, програмного забезпечення, обладнання і т.д. (втрата цілісності);

- блокування транзакцій та/або відключення системи (втрата готовності).

Професійно організована комп'ютерна атака складається з декількох етапів, пов'язаних із визначенням цілей, розвідкою, забезпеченням доступу до системи, безпосередньо реалізацією атаки, знищенням доказів про втручання.

Тому загальний план протидії кібер-нападам повинен включати заходи щодо:

- забезпечення можливості своєчасного виявлення та реагування на кібер-атаки;

- моніторинг та усунення виявлених уразливостей;

- відновлення пошкоджених систем, мереж і устаткування;

- зменшення (мінімізацію) наслідків таких нападів.

До потенційно вразливих складових інформаційної інфраструктури підприемства, що найчастіше використовуються як об'екти нападу при здійсненні атаки на АСУ ТП, можна віднести:

- сервер організації, що має вихід в “зовнішній світ" (піддається постійним атакам через Інтернет);

- персональні мобільні комп'ютери (ноутбуки, планшетні комп'ютери, смартфони тощо), які функціонують на основі загально розповсюдженої ОС, мають уразливі місця та використовуються співробітниками та керівництвом підприемства спільно з робочими (захищеними) комп'ютерами (іноді здійснюеться передача даних між персональним і робочим комп'ютером);

- апаратне забезпечення (комп'ютери) з підключенням до локальної мережі;

- комп’ютери, які мають порти для приеднання зйомних накопичувачів, дисководи для зчитування інформації з оптичних дисків.

Найбільшу загрозу безпеці об'єктів КВО та КІ становлять саме скоординовані атаки з використанням програмних вірусів. Такий вид атаки поєднує підготовчий етап (дії, що створюють на об'єкті нові уразливі місця) та атакуючі дії (використання уразливих місць). При цьому, підготовчі дії можуть здійснюватися значно раніше за часом ніж сама атака, можуть бути задіяні працівники (інсайдери) підприємства, що є об'єктом нападу, та здійснені різноманітні відволікаючі маневри. 


\section{3. Роль фізичного захисту при забезпеченні безпеки АCУ на об'єктах ядерної промисловості}

Особливе значення має надійність АСУ ТП на АЕС, де законодавчо визначена необхідність практичного виключення аварійних ситуацій, які можуть призвести до радіаційного зараження і викиду радіаційних речовин у навколишне середовище. Складовими частинами АСУ ТП е комплекс технічних засобів, оперативний персонал, програмне та інформаційне забезпечення. АСУ ТП мають складну структуру, і , як правило, будуються за технологічним (окремій ділянці об'екту управління відповідає своя підсистема, наприклад, підсистема управління турбіною енергоблоку) та функціональним принципами (наприклад, підсистема збору та обробки інформації) [11].

Функції запобігання проникненню на критично важливі об’єкти покладено на систему фізичного захисту (СФЗ). Згідно рекомендацій МАГАТЕ фрізичний захист формуеться на основі створення і вивчення проектної загрози, яка є описом ознак і характеристик потенційних інсайдерів i/або зовнішніх противників, які могли б здійснити спробу несанкціонованого вилучення ядерного матеріалу або диверсії, i проти яких розробляється і оцінюеться система фрізичного у захисту [12]. СФЗ об’єкту являе собою сукупність організаційних, адміністративних і правових заходів, інженерно-технічних засобів, а також дій підрозділів охорони, що мають в своєму розпорядженні спеціальні засоби, спрямовані на запобігання незаконному втручанню. До інженерно-технічних засобів СФЗ відносять фрізичні бар'ери, сегментацію і допуски, технічні засоби і пристрої, програмне і апаратне забезпечення протидії мережевим кібер-атакам тощо.

Таким чином, захист АСУ ТП є елементом загальної конфігурації СФЗ, що визначається як сукупність підсистем СФЗ, функціонально пов'язаних між собою, що обумовлено основними технічними характеристиками цих підсистем і вимогами фрізичного захисту, що задовольняються виконуються СФЗ.

Розробляючи проектну загрозу необхідно враховувати наступні характеристики загроз та особливості об'єктів, що захищаються [13]:

- можлива присутність на об'єкті внутрішніх правопорушників (інсайдерів), знання та навички, якими можуть вони можуть володіти;

- розуміння цілей зловмисників (диверсія, саботаж, крадіжка інформації тощо);

- національні нормативні документи, що регулюють питання безпеки на об'ектах ядерної інфраструктури, правила, норми тощо.

Ці характеристики допомагають визначити параметри та критерії виявлення, затримки і реагування при розробці СФЗ та оцінці їі ефрективності.

Серед можливих намірів (цілей) зловмисників можна назвати: 
- порушення параметрів технологічного процесу (ТП), що призведе до важкої аварії;

- порушення параметрів ТП або керівний вплив, який призведе до зупинки реактору;

- крадіжка даних, технологічний шпіонаж;

- “таємне” проникнення для здійснення в подальшому координованої атаки.

Для кожної цілі можна побудувати множину ймовірних сценаріїв реалізації атаки, оцінка наслідків якої, як правило, здійснюеться у вигляді комплексного (векторного) показника, що включає як компоненти кількість людських жертв, економічні втрати, час на відновлення системи, екологічні наслідки тощо.

\section{4. Моделювання сценаріїв загроз та оцінка ефективності СФ3}

Побудова ефективної СФЗ для КВО та КІ пов'язана з вирішенням завдання щодо визначення параметрів заходів та засобів, що входять до структури СФЗ. Пошук рішення поставленого завдання параметричного синтезу здійснюеться, як правило, шляхом використання спеціалізованого програмного забезпечення (ПЗ), що дозволяе моделювати множину можливих атак на об'єкт [14]. Важливою складовою таких програмних комплексів є модулі оцінки ефективності СФЗ, в яких реалізовані математичні методи моделювання сценаріїв загроз [15]. В той же час, складність взаємодії програмних та апаратних складових СФЗ, необхідність врахування засобів забезпечення інформаційної безпеки спричиняють певні труднощі для оцінки ефективності СФЗ. Тому існуючі методи моделювання загроз КВО і КІ та оцінки їх захищеності від зловмисного втручання потребують вдосконалення, розширення описових можливостей математичних методів, що застосовуються.

Розглянемо формальну модель опису сценарію загроз КВО та КI. Нехай визначені елементи сценаріїв загроз (засоби виявлення, оснащення та озброєння порушників, бар'єри, засоби оповіщення та зв'язку, датчики та всі інші пристрої, які є суттевими з точки зору реалізації загрози). Позначимо множину елементів сценарію $I=\{1,2, \ldots, n\}$. Нехай задано скінчені множини станів для кожного елементу сценарію $S_{i}=\left\{s_{i}^{(1)}, s_{i}^{(2)}, \ldots, s_{i}^{\left(m_{i}\right)}\right\} \subset Z_{+}^{\prime} i \in I$. Тобто станам елементів надані індекси (невід'ємні цілі значення), наприклад, множиною станів пристрою ідентифрікації фрізичної особи на контрольно-пропускному пункті може бути множина $\{1,2,3\}$, де 1 відповідае безвідмовному спрацюванню пристрою, 2 - відмові (особа, яка має право доступу ідентифрікована як порушник), 3 - відмові (порушнику надано допуск).

Позначимо $x=\left(x_{1}^{\prime} x_{2}^{\prime} \ldots, x_{m}\right)$ - варіант реалізації СФЗ, який обираеться 3 деякої множини можливих варіантів реалізації $X=\prod_{i \in I} X_{i}$. Варіанти реалізації СФЗ можна будувати за принципом “конструктора" з заданих альтернативних варіантів. Кожен з варіантів реалізації 
СФЗ характеризуеться техніко-економічними показниками (вартість, надійність, енерговитратність, час реагування на загрозу). Нехай задана вектор-функція $C(x)$, за допомогою якої варіанти реалізації СФЗ оцінюються за техніко-економічними характеристиками, обмеженими вектором значень $C_{0}$.

Стан елементу сценарію $y_{i}(x, t) \in S_{i}$ залежить від реалізації СФЗ $x \in$ $X$ та моменту часу $t \in T \subset R_{+}$. Нехай можна виділити $m$ різних станів СФЗ, що визначають захищеність (реалізацію чи нейтралізацію певних загроз) об'єкту. Позначимо $S=\left\{s_{1}, s_{2}, \ldots, s_{m}\right\} \subset Z_{+}-$множина станів СФЗ та $y(x, t)$ - стан СФЗ реалізованого варіантом $x \in X$ на момент часу $t \in T$.

Модель опису сценарію $M$ встановлюе зв'язок між станом елементів сценарію $y_{1}(x, t), y_{2}(x, t), \ldots, y_{n}(x, t)$ та станом СФЗ $y(x, t)$, тобто:

$$
M: \prod_{i \in I} S_{i} \rightarrow S .
$$

Функціонування елементів сценарію характеризуеться ймовірностями перебування елементів у відповідних станах $p_{i}^{(s)}(x, t)=P\left\{y_{i}(x, t)=\right.$ $s\}, s \in S_{i}, t \in T, i \in I$. На основі моделі опису сценарію $M$, ймовірнісних характеристик елементів сценарію та із застосуванням логікоймовірнісного методу визначаеться $p^{(s)}(x, t)=P\{y(x, t)=s\}, s \in S-$ ймовірність перебування СФЗ в певних станах [16].

Нехай ефективність СФЗ можна оцінити деяким заданим критерієм $F(\cdot)$, що залежить від ймовірнісних характеристик стану, в якому СФЗ перебуває протягом інтервалу часу $T$. Тоді загальна постановка задачі підвищення ефективності СФЗ для КВО та КІ має наступний вигляд:

$$
F(p(x, t), T) \rightarrow e x t r,
$$

з врахуванням обмежень на використання ресурсів та вибору варіанту реалізації елементів СФЗ:

$$
\begin{gathered}
C(x) \leqslant C_{0}, \\
x \in X .
\end{gathered}
$$

Представлена постановка задачі е узагальненою, а її розв'язування потребує застосування як спеціальних методів логіко-ймовірнісного аналізу, так і оптимізаційних процедур, побудованих з урахуванням сформованого (формалізованого) критерію ефективності СФЗ, який співвідноситься з конкретним КВО та КI, або певною ситуацією, що склалася чи може скластися на цих об'ектах.

\section{Висновки}

Останнім десятиліттям все частіше при створенні АСУ та АСУ ТП використовуються мережеві технології обміну інформацією, що дозволяє здійснювати відділений доступ до елементів накопичення і обробки інформації (адміністрація веб-серверів, СУБД тощо). Це призвело до зростання ризику можливого здійснення терористичних атак на АСУ ТП 
для КВО та КІ. Про ступінь загрози свідчать непоодинокі випадки зараження контролерів АСУ ТП на промислових підприемствах вірусом Stuxnet з тяжкими наслідками.

На сьогодні серед показників ефективності СФЗ треба розглядати спроможність протистояти спробам зараження внутрішніх програмних і апаратних засобів, що здійснюються з метою подальшого зловмисного впливу на АСУ ТП. В нормативному плані доцільно здійснити перегляд стандартів, норм, практики застосування стандартів безпеки на КВО та KI. В якості зразку, що може бути поширений на КВО та КI, доцільно використовувати вітчизняний та міжнародний досвід запровадження СФЗ на об'єктах ядерної промисловості.

\section{Література}

1. Ястребенецкий М.А., Иванова Г.М. Надежность автоматизированных систем управлення технологическими процессами. - М.: Энергоатомиздат, 1989. - $264 \mathrm{c}$.

2. Основы теории надежности автоматических систем управления / Л.П.Глазунов, В.П.Грабовский, О.В.Щербаков. - Л.: Энергоатомиздат, Ленингр.отд-ние, 1984. - 208 с.

3. ГОСТ 24.701-86 - Единая система стандартов автоматизированных систем управления. Надежность автоматизированных систем управления. Основные положения.

4. Черкесов Г.Н. Надежность аппаратно-программных комплексов. Спб.: Надежность аппаратно-программных комплексов. Учебное пособие. - СПб.: Питер, 2005. - 479 с:

5. Erbschloe M. Physical security for IT. - Elsevier Inc., 2005. - 231 p.

6. Критически важные объекты и кибертерроризм. - М.: Изд-во МЦНМО, 2008. - Ч.2: Аспекты программной реализации средств противодействия. $-607 \mathrm{c}$.

7. US Computer Emergency Readiness Team [Електронний ресурс] / Peжим доступу [Веб-сайт]: http://www.us-cert.gov

8. Stuxnet Dossier // Symantec Security Response. - February. - 2011. $68 \mathrm{p}$.

9. The precursor to the next Stuxnet // Symantec Security Response. November. $-2011 .-46 \mathrm{p}$.

10. ICS-CERT Monthly Monitor [Електронний pecypc]. - April. - 2012. - Режим доступу: http://www.us-cert.gov/control_systems/pdf/ICSCERT_Monthly_Monitor_Apr2012.pdf

11. Безопасность атомных станций. Информационные и управляющие системы / М.А. Ястребенецкий (ред.). - К.: Техника, 2004. - 471 с.

12. Nuclear Security Recommendations on Physical Protection of Nuclear Material and Nuclear Facilities (INFCIRC/225/Rev.5) [Текст]. - Vienna: IAEA, 2011. $-57 \mathrm{p}$. 
13. Оцінка загрози ядерного тероризму: проектна загроза [Текст] / CI. Кондратов, Ю.М. Скалецький, B.I. Кравцов та ін.; за заг. ред. акад. НАН України В.П. Горбуліна - К.: ДП "НВЦ"Свроатлантикінформ 2006. - 76 с.

14. Бояринцев А.В. Проблемы антитерроризма: угрозы и модели нарушителей / А.В. Бояринцев, А.Г. Зуев., А.В. Ничиков - СПб.: ЗАО "НПП "ИСТА-Системс", 2008. - 220 с.

15. Боровский А.С., Тарасов А.Д. Интегрированный подход к разработке общей модели функционирования систем физической защиты объектов // Труды ИСА РАН. - Том 61 (1). - 2011. - С. 3 - 13.

16. Моделювання та оцінка сценаріїв загроз для об'єктів критичної інфраструктури [Текст] / Д.С.Бірюков, В.А.Заславський, В.В.Свгієнко, О.В.Франчук // Наукові записки НаУКМА. - 2009. Том 99: Комп’ютерні науки. - С. 97 - 102.

Отримано 26.11.2012 p. 